Jurnal Manajemen dan Bisnis, Volume 2, No. 1, Juli 2020

\title{
PENGARUH MODAL SAHAM DAN UTANG TERHADAP PROFITABILITAS PERUSAHAAN KOSMETIK DAN KEPERLUAN RUMAH TANGGA DI BURSA EFEK INDONESIA PERIODE 2016-2018
}

\author{
Anggun Lianata $\operatorname{Sari}^{1}$, Saprudin $^{2}$, Sita Dewi $^{3}$ \\ Sekolah Tinggi Ilmu Ekonomi Jayakarta \\ Anggunls17@gmail.com ${ }^{1}$, saprudinmaksudi@gmail.com², \\ sitadewi.27@gmail.com ${ }^{3}$
}

\begin{abstract}
ABSTRAK
Perusahaan kosmetik dan keperluan rumah tangga mempunyai peranan penting dalam kehidupan manusia. Kosmetik dan keperluan rumah tangga merupakan kebutuhan yang penting bagi masyarakat modern. Tujuan penelitian ini adalah untuk menggetahui apakah ada pengaruh signifikan dari Modal Saham, Utang terhadap Profitabilitas. Populasi dalam penelitian ini adalah 4 Perusahaan Kosmetik dan Keperluan Rumah Tangga di Bursa Efek Indonesia periode 2016-2018. Teknik analisis data menggunakan analisis regresi linear berganda pada program SPSS 20.0. Hasil penelitian ini menjelaskan bahwa Modal Saham dan Utang mempunyai pengaruh yang signifikan terhadap Profitabilitas, dapat dilihat dari hasil analisis linear berganda.
\end{abstract}

Kata Kunci: Modal Saham, Utang, Profitabilitas

\section{ABSTRACT}

Cosmetics companies and household needs have an important role in human life. Cosmetics and household needs is an important requirement for modern society. The purpose of this stufy is to find out whether there is a significant influence of Equity Capital, Debt, on Probability. The population in this study were 4 Cosmetics Companies and Household Purposes on the Indonesia Stock Exchange in the 2016-2018 period. Data analysis techniques used multiple linear regression analysis in the SPSS 20.0 program. The result of this study explain that Equity Capital and Debt has a significant effect on Probability, it can be seen from the results of multiple linear analyzes.

Keywords: Capital Stock, Debt, Probability

Korespondensi : Saprudin. Email : saprudinmaksudi@gmail.com

\section{PENDAHULUAN}

Perkembangan industri kosmetik dan barang keperluan rumah tangga di Indonesia terus meningkat menyebabkan perusahaan ini bisa dibilang memiliki potensi yang menjanjikan untuk dikembangkan dan memiliki peluang investasi yang bagus. Hal ini juga didukung dengan meningkatnya pertumbuhan penduduk di Indonesia, sehingga permintaan akan produk kosmetik dan barang keperluan rumah tangga juga semakin meningkat serta peluang tren kosmetik halal yang mulai berkembang pesat di Indonesia.

Fenomena yang terjadi disektor kosmetik dan barang keperluan rumah tangga masih kurang cantik sepanjang semester I. Menurut Analis Panin Sekuritas, William Hartanto 
menjelaskan produk kosmetik dalam negeri tertekan dengan produk impor yang harganya lebih murah sehingga konsumen tentu beralih ke produk yang lebih pas dikantong.

William mengatakan ada kemungkinan jika impor dibatasi pada paruh kedua tahun ini keadannya bisa lebih membaik. Kendati demikian, momentum sepanjang paruh kedua tahun ini belum bisa mendongkrak kinerjanya. Dari segi sentiment belum ada yang mendukung kenaikan emiten-emiten disektor kecantikan. (investasi.kontan.co.id - Jakarta, 10 Agustus 2019).

Profitabilitas atau laba merupakan hasil akhir bersih dari operasi perusahaan dengan berbagai kebijakan dan keputusan manajemen. Agar dapat memaksimalkan laba yang didapat perusahaan, manajer keuangan perlu mengetahui faktor-faktor yang memiliki pengaruh besar terhadap profitabilitas perusahaan.

Profitabilitas menggambarkan kemampuan perusahaan mendapatkan laba melalui semua kemampuan dan sumber yang ada seperti penjualan, kas, modal, jumlah karyawan, jumlah cabang, dan sebagainya. Profitabilitas diukur dengan kemampuan dari modal yang diinvestasikan dalam keseluruhan aktiva untuk menghasilkan keuntungan bagi semua investor.

Sedangkan utang adalah semua kewajiban keuangan perusahaan kepada pihak lain yang belum terpenuhi, yang umumnya berupa pembayaran uang dan penyerahan produk pada waktu yang telah disepakati bersama. Tidak berarti perusahaan yang memiliki utang bukan berarti dalam keadaan yang tidak baik dan akan mengalami kerugian atau kepailitan.

Seperti fenomena pada PT. Nyonya Meneer yang mengalami kebangkrutan dikarenakan tak mampu membayar utang sebesar 267 Miliar rupiah kepada sejumlah kreditur, selain itu sebelumnya perusahaan tersebut mengalami krisis operasional yang sehingga perusahaan tidak dapat menjalankan serta memaksimalkan potensi yang dimilki oleh perusahaan dalam mendapatkan keuntungan.

Menurut anggota majelis hakim PN Niaga Semarang, Wismonoto, mengatakan bahwa pihak penggugat mengajukan gugatan karena tidak puas atas proses pembayaran hutang sebagaimana diatur dalam perjanjian damai (tribunwow.com, 5 Agustus 2017).

Hal tersebut menunjukkan resiko utang sangat berpengaruh terhadap kelangsungan perusahaan dikarenakan utang sangat berpengaruh terhadap aset dan modal yang dikeluarkan oleh perusahaan.

Modal saham merupakan jenis modal yang hanya terdapat dalam perusahaan yang berbentuk Perseroan Terbatas (PT) yang diperoleh dengan cara menerbitkan dan menempatkan saham-saham tersebut kepada pihak tertentu atau kepada masyarakat umum. Tingkat kepemilikan pemegang saham terhadap perusahaan tergantung seberapa besar bagian saham yang dikuasinya.

Saham mempunyai keunggulan dari pada pendanaan lainnya, karena mempunyai mekanisme yang dapat mengumpulkan dana dalam waktu yang cepat. Naik turunnya saham dipengaruhi kinerja perusahaan yang dilihat dalam laporan keuangan. Selain perusahaan yang mendapatkan keuntungan, pemilik saham mendapatkan keuntungan yang diperoleh dari selisih harga jual saham (capital gain) dan dividend.

Peneliti melihat untuk bisnis sektor kosmetik dan keperluan rumah tangga 
Jurnal Manajemen dan Bisnis, Volume 2, No. 1, Juli 2020

mempunyai masa depan yang cerah. Pandangan ini bisa dilihat dari beberapa sudut pandang dan salah satunya ialah kosmetik dan barang keperluan rumah tangga sebagai usaha investasi masa depan. Kosmetik dan barang keperluan rumah tangga mempunyai prospek yang baik, dikarenakan sedang meningkatnya tren penampilan yang terjadi sehingga membutuhkan kosmetik dan barang keperluan rumah tangga sebagai alat penunjang penampilan.

\section{KAJIAN LITERATUR}

Agency theory menurut Adrian Sutedi (2015:76-77) merupakan teori yang menjelaskan tentang hubungan kontraktual antara pihak yang mendelegasikan pengambilan keputusan tertentu (principal) pemilik/pemegang saham dan pihak yang menerima pendelegasian tersebut (agent) direksi/manajemen. Agency theory memfokuskan pada penentuan kontrak yang paling efisien yang mempengaruhi hubungan prinsipal dan agen.

Tujuan dipisahkannya pengelolaan dari kepemilikan perusahaan adalah agar pemilik perusahaan memperoleh keuntungan yang semaksimal mungkin dengan biaya yang seefisien mungkin dengan dikelolanya perusahaan oleh tenaga-tenaga profesional.

Menurut Yoyo Sudaryo, dkk (2017: 61), hal terpenting dalam teori agensi adalah kewenangan yang diberikan kepada agen untuk melakukan suatu tindakan dalam hal kepentingan pemilik. Teori agensi menghasilkan cara yang penting untuk menjelaskan kepentingan yang berlawanan antara manajer dengan pemilik yang merupakan suatu rintangan.

Menurut Hestanto (2019) mengemukakan bahwa pihak ketiga yang independen sebagai mediator pada hubungan antara prinsipal dan agen.
Pihak ketiga ini berfungsi untuk memonitor perilaku manajer (agen) apakah sudah bertindak dengan tepat sesuai dengan keinginan prinsipal (pemilik atau pemegang saham).

Menurut Irham Fahmi (2014:31) laporan keuangan merupakan suatu informasi yang menggambarkan kondisi keuangan suatu perusahaan, dan lebih jauh informasi tersebut dapat dijadikan sebagai gambaran kinerja keuangan perusahaan tersebut.

Menurut Hery (2018:6-7) tujuan khusus laporan keuangan adalah menyajikan posisi keuangan, hasil usaha, dan perubahan posisi keuangan lainnya secara wajar dan sesuai dengan prinsipprinsip akuntansi yang berlaku generally accepted accounting principles (GAAP).

Salah satu cara memperoleh informasi yang bermanfaat dari laporan keuangan perusahaan adalah dengan melakukan analisis rasio keuangan, salah satunya rasio profitabilitas.

Menurut Munawir (2014:33) definisi profitabilitas adalah sebagai berikut "Rentabilitas atau profitability adalah menunjukkan kemampuan perusahaan untuk menghasilkan laba selama periode tertentu. Rentabilitas suatu perusahaan diukur dengan kesuksesan perusahaan dan kemampuan menggunakan aktivanya secara produktif, dengan demikian rentabilitas suatu perusahaan dapat diketahui dengan membandingkan antara laba yang diperoleh dalam suatu periode dengan jumlah aktiva atau jumlah modal perusahaan tersebut.

Berdasarkan definisi diatas dapat diketahui bahwa profitabilitas merupakan kemampuan perusahaan dalam memperoleh laba selama periode tertentu dengan modal atau aktiva yang dimiliki oleh perusahaan.

Menurut Irham Fahmi (2014:79) pengertian rasio profitabilitas adalah 


\section{Jurnal Manajemen dan Bisnis, Volume 2, No. 1, Juli 2020}

resiko ini mengatur efektivitas manajemen secara keseluruhan yang ditujukan oleh besar kecilnya tingkat keuntungan yang diperoleh dalam hubungannya dengan penjualan maupun investasi. Dari definisi-definisi di atas, dapat disimpulkan bahwa rasio profitabilitas adalah rasio yang digunakan untuk mengukur kemampuan dan keberhasilan perusahaan dalam memperoleh laba yang hubungannya dengan penjualan, aktiva maupun investasi.

Menurut Kasmir (2016:196) "Rasio profitabilitas merupakan rasio untuk menilai kemampuan perusahaan dalam mencari keuntungan". Rasio ini dapat juga memberikan ukuran tingkat efektivitas manajemen suatu perusahaan. Hal ini ditunjukkan oleh adanya laba yang dihasilkan dari penjualan dan pendapatan investasi. Inti dari penggunaan rasio ini adalah untuk menunjukkan efisiensi perusahaan.

Tujuan dan manfaat penggunaan rasio profitabilitas menurut Kasmir (2016:197), adalah:

1. Untuk mengukur atau menghitung laba yang diperoleh perusahaan dalam satu periode tertentu.

2. Untuk menilai posisi laba perusahaan tahun sebelumnya dengan tahun sekarang.

3. Untuk menilai perkembangan laba dari waktu ke waktu.

4. Untuk menilai besarnya laba bersih sesudah pajak dengan modal sendiri.

5. Untuk mengukur produktivitas seluruh dana perusahaan yang digunakan baik modal pinjaman maupun modal sendiri.

Modal saham menurut Rudianto (2018:227-235) merupakan jenis modal yang hanya terdapat dalam perusahaan yang berbentuk Perseroan Terbatas (PT) yang diperoleh dengan cara menerbitkan dan menempatkan saham-saham tersebut kepada pihak tertentu atau kepada masyarakat umum. Tingkat kepemilikan pemegang saham terhadap perusahaan tergantung seberapa besar bagian saham yang dikuasinya.

Bila perusahaan penerbit mampu menghasilkan laba yang besar maka ada kemungkinan para pemegang sahamnya akan menikmati keuntungan yang besar pula (M. Suparmoko dan Icuk Rangga Bawana. 2007:67).

Apabila perusahaan mengeluarkan dua macam saham, maka saham-saham tersebut adalah saham biasa dan yang lain adalah saham prioritas (preferred stock). Apabila perusahaan mengeluarkan satu macam saham, maka saham-saham itu disebut saham biasa (common stock). Berikut ini diuraikan mengenai masing-masing jenis saham:

Klasifikasi saham menurut Ali Akbar Yulianto (2007:404) dalam buku yang berjudul Pengantar Bisnis yaitu: saham biasa dan saham preferen.

Menurut Hery (2016:202) utang adalah kewajiban yang diperkirakan akan dibayar dengan menggunakan aktiva lancar atau menciptakan kewajiban lancar lainnya dan harus segera dilunasi dalam jangka waktu satu tahun.

Utang menurut Irham Fahmi (2014:153-154) adalah kewajiban (liabilities). Maka liabilities atau utang merupakan kewajiban yang dimiliki oleh pihak perusahaan yang bersumber dari dana eksternal baik yang berasal dari sumber pinjaman perbankan, leasing, penjualan obligasi. Kewajiban adalah saldo kredit atau jumlah yang harus dipindahkan dari saat tutup buku ke periode tahun berikutnya berdasarkan pencatatan yang sesuai dengan prinsip akuntansi (saldo kredit bukan akibat saldo negatif aktiva). 
Jurnal Manajemen dan Bisnis, Volume 2, No. 1, Juli 2020

Karena itu suatu kewajiban adalah mewajibkan bagi perusahaan melaksanakan kewajiban tersebut, dan jika kewajiban tersebut tidak dilaksanakan secara tepat waktu akan memungkinkan bagi suatu perusahaan menerima sanksi dan akibat. Sanksi dan akibat yang diperoleh tersebut berbentuk pemindahan kepemilikan aset pada suatu saat. Karena itu bagi beberapa kreditur yang memberikan pinjaman kepada debitur menginginkan adanya jaminan dari setiap pinjaman tersebut, seperti tanah, bangunan, kendaraan, dan berbagai bentuk aktiva lainnya khususnya akitiva tetap.

Klasifikasi utang menurut Irham Fahmi (2014:154) dibagi menjadi dua macam, yaitu utang jangka pendek dan utang jangka panjang.

Untuk mengetahui hubungan antara variable independent dengan variable devendent yang digunakan dalam penelitian ini dapat dilihat pada:

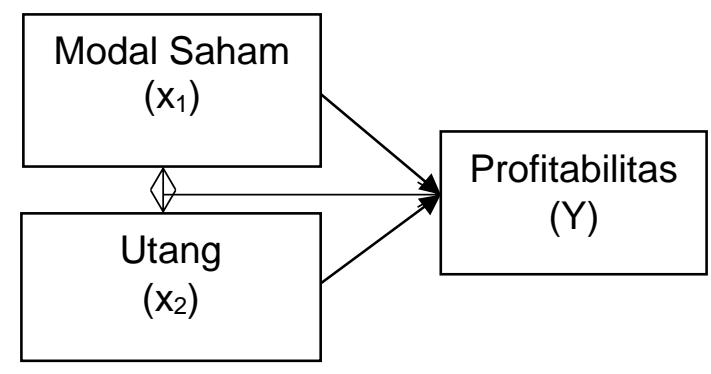

Hipotesis merupakan jawaban sementara terhadap rumusan masalah penelitian, oleh karena itu rumusan masalah penelitian biasanya disusun dalam bentuk pertanyaan. Dikatakan sementara. Karena jawaban yang diberikan baru berdasarkan pada teori yang relevan, belum berdasarkan faktafakta yang empiris melalui pengumpulan data. Jadi hipotesis juga dapat dinyatakan sebagai jawaban teoritis terhadap rumusan masalah penelitian, belum jawaban yang empiris (Sugiyono, 2016:93). Dari rumusan yang dikemukakan penulis dapat menyusun kesimpulan sementara bahwa:

$\mathrm{H}_{1}$ : Modal Saham berpengaruh signifikan terhadap Profitabilitas perusahaan kosmetik dan keperluan rumah tangga

$\mathrm{H}_{2}$ : Utang berpengaruh signifikan terhadap Profitabilitas perusahaan kosmetik dan keperluan rumah tangga

$\mathrm{H}_{3}$ : Modal Saham dan Utang berpengaruh signifikan terhadap Profitabilitas perusahaan kosmetik dan keperluan rumah tangga

\section{METODE}

Berdasarkan sifat data yang digunakan pada penelitian ini maka dapat disimpulkan bahwa penelitian ini adalah jenis penelitian kuantitatif, yaitu metodelogi kuantittif sebagai prosedur penelitian yang menghasilkan data berupa angka-angka dan umumnya dianalisa dengan menggunakan statistik deskriptif atau inferensial. Dalam penelitian ini, metode penelitian kuantitatif digunakan untuk meneliti pada sampel dengan menggunakan instrument penelitian dengan tujuan untuk menguji hipotesis yang telah dirumuskan.

Statiska deskriptif adalah metodemetode yang berkaitan dengan pengumpulan dan penyajian suatu gugus data sehingga memberikan informasi yang berguna. Statiska inferensial adalah mencakup semua metode yang berhubungan dengan analisis sebagian data atau juga sering disebut dengan sampel untuk kemudian sampai pada peramalan atau penarikan kesimpulan mengenai keseluruhan data induknya (populasi). Pengklasifikasian menjadi statiska deskriptif dan statiska inferensial dilakukan berdasarkan aktivitas yang dilakukan. 
Jurnal Manajemen dan Bisnis, Volume 2, No. 1, Juli 2020

Menurut Sugiyono (2016:11) pengertian kedua penelitian tersebut adalah sebagai berikut: "Penelitian deskriptif adalah penelitian yang dilakukan untuk mengetahui nilai variabel baik satu variabel atau lebih (independen) tanpa membuat pembandingan atau hubungan dengan variable lain". Sedangkan penelitian inferensial adalah suatu penelitian yang ditujukan untuk menguji teori dan akan mencoba menghasilkan metode ilmiah yakni status hipotesis yang berupa kesimpulan, apakah suatu hipotesis diterima atau ditolak. Penelitian inferensial merupakan penelitian yang digunakan untuk menguji hipotesis dengan menggunakan perhitungan statiska infrensial.

Menurut Sofar Silaen (2018:19), "Penelitian deskriptif adalah penelitian yang bertujuan untuk memberikan deskriptif, gambaran mengenai faktafakta, sifat-sifat, serta hubungan antar fenomena yang diteliti, termasuk hubungan kegiatan-kegiatan, sikapsikap, pandangan-pandangan, serta proses-proses yang sedang berlangsung dan pengaruh-pengaruh dari suatu fenomena, atau untuk menentukan frekuensi distribusi suatu gejala atau frekuensi adanya hubungan tertentu antara suatu gejala dengan gejala lain".

Jenis penelitian yang digunakan berdasarkan sumber datanya adalah penelitian perpustakaan. Penelitian perpustakaan adalah penelitian yang dilakukan untuk mendapatkan data sekunder yang diperlukan, antara lain: modal saham, utang, profitabilitas, laporan keuangan PT Kosmetik dan Keperluan rumah tangga.

Berdasarkan pendekatan pemakaiannya, jenis penelitian yang digunakan adalah penelitian terapan. Tujuan penelitian ini dipergunakan atau diimplementasikan dalam mengatasi masalah mengenai pengaruh modal saham, dan utang terhadap profitabilitas di Perusahaan Kosmetik dan Keperluan rumah tangga, berupa laporan keuangan Perusahaan Kosmetik dan Keperluan rumah tangga di Bursa Efek Indonesia (BEI) meliputi laporan neraca, dan laporan laba/rugi selama kurun waktu 3 tahun terakhir (2016-2018).

Dalam penelitian ini yang termasuk dalam variabel independen adalah:

Modal Saham $\left(\mathrm{X}_{1}\right)$

Untuk mengetahui modal sahamnya, peneliti menggunakan rasio modal. Rasio modal atau capital ratio yaitu nisbah keuangan yang mengukur kecukupan modal dikaitkan dengan asset atau kewajibannya.

Rumus perhitungannya adalah:

$$
\begin{aligned}
& \text { Ratio Modal Asset }=\frac{\text { Modal sendiri }}{\text { Total aset }}=\times 100 \% \\
& \text { Utang }\left(\mathrm{X}_{2}\right)
\end{aligned}
$$

Untuk mengetahui utang, peneliti menggunakan perhitungan debt to equity ratio. Rasio hutang dengan modal sendiri (debt to equity ratio) adalah imbangan antara utang yang dimiliki perusahaan dengan modal sendiri. Semakin tinggi ratio ini berarti modal sendiri semakin sedikit di banding dengan utangnya. Bagi perusahaan sebaliknya, besarnya utang tidak boleh melebihi modal sendiri agar modal tetapnya tidak terlalu tinggi. Semakin kecil rasio ini maka semakin baik. Maksudnya, semakin kecil porsi utang terhadap modal maka semakin aman. Dengan menggunakan rumus:

$$
D E R=\frac{\text { Total Liabilities }}{\text { Ekuitas }} \times 100 \%
$$

Variabel dependen dalam penelitian ini adalah profitabilitas yang diberi simbol (Y) yang diukur menggunakan Net Profit Margin (NPM), adalah mengukur besarnya laba bersih 
Jurnal Manajemen dan Bisnis, Volume 2, No. 1, Juli 2020

perusahaan dibandingkan dengan penjualannya.

NPM didefinisikan sebagai berikut, Net Profit Margin adalah merupakan rasio antara laba bersih (Net Profit Margin) yaitu penjualan sesudah dikurangi dengan seluruh expense termasuk pajak dibandingkan dengan penjualan. Semakin tinggi NPM maka semakin baik operasi suatu perusahaan. Dengan menggunakan rumus:

$\mathrm{NPM}=\frac{\text { Laba Bersih Setelah Pajak }}{\text { Penjualan }} \times 100 \%$

Dalam penelitian ini, peneliti menggunakan teknik dokumentasi yaitu teknik pengumpulan data dengan cara mengambil data di Bursa Efek Indonesia (BEI) melalui dokumen-dokumen yang ada PIPM (Pusat Informasi Pasar Modal). Adapun data yang dikumpulkan adalah data laporan keuangan yang meliputi laporan neraca dan laporan laba rugi selama kurun waktu 3 tahun pada perusahaan Kosmetik dan Keperluan rumah tangga pada kurun waktu 2016 sampai periode 2018.

Sampel sebagai tempat penelitian sebanyak 4 perusahaan yaitu, Akasha Wira Internasional Tbk. Kino Indonesia Tbk. Mandom Indonesia Tbk. Unilever Indonesia Tbk. Peneliti mengambil sampel ini dikarenakan perusahaan tersebut tidak mengalami kerugian dalam periode yang ditentukan oleh peneliti.

Dalam penelitian ini, metode yang digunakan untuk mengambil sampel dengan menggunakan teknik purposive sampling, alasan menggunakan teknik purposive sampling adalah karena tidak semua sampel memiliki kriteria yang sesuai dengan yang telah penulis tentukan. Oleh karena itu, penulis memilih teknik purposive sampling dengan menetapkan pertimbanganpertimbangan atau kriteria-kriteria tentu yang harus dipenuhi oleh sampel-sampel yang akan digunakan dalam penelitian ini.

Didalam menganalisis data, metode yang dipakai adalah statistik yang diharapkan dapat membantu dalam mengambil keputusan menerima atau menolak hipotesis. Pada proses perhitungannya dilakukan dengan menggunakan program aplikasi komputer Statiscal Package For The Social Science (SPSS 24.0 for Windows). Uji asumsi klasik dan uji regresi dilakukan untuk mengetahui besarnya pengaruh antar variabel dan hipotesis.

\section{HASIL DAN PEMBAHASAN}

Penelitian ini menggunakan data sekunder berupa laporan keuangan perusahaan sub-sektor kosmetik dan keperluan rumah tangga yang telah terdaftar di Bursa Efek Indonesia (BEI) tahun 2016-2018. Data tersebut diambil dari Bursa Efek Indonesia (BEI) dan www.idx.co.id . Teknik pengambilan sampel menggunakan purpose sampling. Kriteria dalam pengambilan sampel, yaitu:

1. Perusahaan sub-sektor kosmetik dan keperluan rumah tangga yang terdaftar pada Bursa Efek Indonesia selama periode tahun 2016-2018.

2. Perusahaan sub-sektor kosmetik dan keperluan rumah tangga yang telah menerbitkan laporan keuangan neraca, laba atau rugi perusahaan selama 3 tahun selama periode tahun 2016-2018.

3. Perusahaan yang mempunyai kelengkapan data variabel (Ratio modal asset, Debt to equity dan Net Profit Margin) yang dibutuhkan selama periode tahun 2016-2018.

Berdasarkan kriteria tersebut diperoleh empat perusahaan kosmetik dan keperluan rumah tangga yang 
Jurnal Manajemen dan Bisnis, Volume 2, No. 1, Juli 2020

terdaftar di Bursa Efek Indonesia (BEI) dan akan digunakan untuk mengambil laporan keuangan perusahaan yang termasuk dalam perusahaan kosmetik dan keperluan rumah tangga periode tahun 2016-2018 ditunjukkan pada tabel berikut ini:

Data Ratio Modal Asset (dalam jutaan rupiah)

\begin{tabular}{|c|c|c|c|c|}
\hline \multirow{2}{*}{$\begin{array}{c}\text { Nama } \\
\text { Perusahaan }\end{array}$} & \multirow{2}{*}{$\begin{array}{l}\text { Tah } \\
\text { un }\end{array}$} & \multicolumn{2}{|c|}{ Modal Sendiri } & \multirow{2}{*}{$\begin{array}{l}\text { Rasio } \\
\text { Moda } \\
1 \\
\text { Asset }\end{array}$} \\
\hline & & $\begin{array}{l}\text { Total } \\
\text { Ekuitas }\end{array}$ & $\begin{array}{l}\text { Total } \\
\text { Aktiva }\end{array}$ & \\
\hline \multirow{4}{*}{$\begin{array}{l}\text { Akasha Wira } \\
\text { Internasional } \\
\text { Tbk }\end{array}$} & $\begin{array}{r}201 \\
6 \\
\end{array}$ & 384.388 & 767.479 & 50,08 \\
\hline & 201 & & & \\
\hline & 7 & 423.011 & 840.236 & 50,34 \\
\hline & $\begin{array}{r}201 \\
8 \\
\end{array}$ & 458.569 & 876.218 & 52,34 \\
\hline \multirow{4}{*}{$\begin{array}{l}\text { Kino } \\
\text { Indonesia } \\
\text { Tbk }\end{array}$} & $\begin{array}{r}201 \\
6 \\
\end{array}$ & $\begin{array}{r}1.952 .07 \\
2 \\
\end{array}$ & 3.284 .504 & 59,43 \\
\hline & 201 & 2.055 .17 & & \\
\hline & 7 & 1 & 3.237 .595 & 63,48 \\
\hline & $\begin{array}{r}201 \\
8 \\
\end{array}$ & $\begin{array}{r}2.115 .04 \\
1 \\
\end{array}$ & 3.506 .699 & 60,31 \\
\hline \multirow{3}{*}{$\begin{array}{l}\text { Mandom } \\
\text { Indonesia } \\
\text { Tbk }\end{array}$} & $\begin{array}{r}201 \\
6\end{array}$ & $\begin{array}{r}1.783 .15 \\
9\end{array}$ & 2.185 .101 & 81,61 \\
\hline & $\begin{array}{r}201 \\
7\end{array}$ & $\begin{array}{r}1.858 .32 \\
6\end{array}$ & 2.361 .807 & 78.68 \\
\hline & $\begin{array}{r}201 \\
8\end{array}$ & $\begin{array}{r}1.956 .83 \\
3\end{array}$ & 2.433 .645 & 80,41 \\
\hline \multirow{4}{*}{$\begin{array}{l}\text { Unilever } \\
\text { Indonesia } \\
\text { Tbk }\end{array}$} & $\begin{array}{r}201 \\
6\end{array}$ & $\begin{array}{r}4.704 .25 \\
8\end{array}$ & 16.745 .695 & 28,09 \\
\hline & 201 & 5.173 .38 & & \\
\hline & 7 & 8 & 18.906 .413 & 27,36 \\
\hline & $\begin{array}{r}201 \\
8\end{array}$ & $\begin{array}{r}7.578 .13 \\
3\end{array}$ & 19.522 .970 & 38,82 \\
\hline
\end{tabular}

Adapun untuk perhitungan rasio utang terhadap modal selama tahun 2016 sampai dengan 2018 terlihat dalam tabel berikut ini.

Data Debt to Equity Ratio (DER) (dalam jutaan rupiah)

\begin{tabular}{|c|c|c|c|c|}
\hline \multirow{2}{*}{$\begin{array}{c}\text { Nama } \\
\text { Perusahaan }\end{array}$} & \multirow{2}{*}{$\begin{array}{l}\text { Tah } \\
\text { un }\end{array}$} & \multicolumn{2}{|c|}{ Utang } & \multirow{2}{*}{ DER } \\
\hline & & $\begin{array}{l}\text { Total } \\
\text { Liabilities }\end{array}$ & $\begin{array}{l}\text { Total } \\
\text { Ekuitas }\end{array}$ & \\
\hline \multirow{3}{*}{$\begin{array}{l}\text { Akasha } \\
\text { Wira } \\
\text { Internasiona } \\
1 \text { Tbk }\end{array}$} & $\begin{array}{r}201 \\
6 \\
\end{array}$ & 383.091 & 384.388 & 99,66 \\
\hline & $\begin{array}{r}201 \\
7\end{array}$ & 417.225 & 423.011 & 98,63 \\
\hline & $\begin{array}{r}201 \\
8\end{array}$ & 417.649 & 458.569 & 91,08 \\
\hline \multirow{4}{*}{$\begin{array}{l}\text { Kino } \\
\text { Indonesia } \\
\text { Tbk }\end{array}$} & $\begin{array}{r}201 \\
6\end{array}$ & 1.332 .432 & 1.952 .072 & 68,26 \\
\hline & $\begin{array}{r}201 \\
7\end{array}$ & 1.182 .424 & 2.055 .171 & 57,53 \\
\hline & $\begin{array}{r}201 \\
8\end{array}$ & 1.391 .658 & 2.115 .041 & 65,80 \\
\hline & $\begin{array}{r}201 \\
6\end{array}$ & 401.943 & 1.783 .159 & 22,54 \\
\hline
\end{tabular}

\begin{tabular}{|l|r|r|r|r|} 
Mandom & 201 & & & \\
Indonesia & 7 & 503.481 & 1.858 .326 & 27,09 \\
\cline { 2 - 5 } & 201 & & & \\
& 8 & 476.813 & 1.956 .833 & 24,37 \\
\hline & 201 & & & \\
Unilever & 6 & 12.041 .437 & 4.704 .258 & 255,97 \\
\cline { 2 - 5 } Indonesia & 701 & & & \\
Tbk & 201 & 13.733 .025 & 5.173 .388 & 265,46 \\
\cline { 2 - 5 } & 8 & 11.944 .837 & 7.578 .133 & 157,62 \\
\hline
\end{tabular}

Perhitungan Net Profit Margin untuk tahun 2016 sampai dengan 2018 atas laporan keuangan yang diambil dalam sampel penelitian ini adalah sebagai berikut.

Data Net Profit Margin (dalam jutaan rupiah)

\begin{tabular}{|c|c|c|c|c|}
\hline \multirow{2}{*}{$\begin{array}{c}\text { Nama } \\
\text { Perusahaan }\end{array}$} & \multirow{2}{*}{$\begin{array}{c}\text { Tahu } \\
\mathrm{n}\end{array}$} & \multicolumn{2}{|c|}{ Profitabilitas } & \multirow{2}{*}{ NPM } \\
\hline & & $\begin{array}{l}\text { Laba } \\
\text { Bersih }\end{array}$ & Penjualan & \\
\hline \multirow{3}{*}{$\begin{array}{l}\text { Akasha Wira } \\
\text { Internasional } \\
\text { Tbk }\end{array}$} & 2016 & 55.951 & 887.663 & 6,30 \\
\hline & 2017 & 38.242 & 814.490 & 4,70 \\
\hline & 2018 & 35.558 & 596.529 & 5,96 \\
\hline \multirow{3}{*}{$\begin{array}{l}\text { Kino } \\
\text { Indonesia } \\
\text { Tbk }\end{array}$} & 2016 & 181.110 & 3.493 .029 & 5,18 \\
\hline & 2017 & 109.696 & 2.055 .171 & 5,34 \\
\hline & 2018 & 105.297 & 2.115 .041 & 4,98 \\
\hline \multirow{3}{*}{$\begin{array}{l}\text { Mandom } \\
\text { Indonesia } \\
\text { Tbk }\end{array}$} & 2016 & 162.060 & 2.526 .776 & 6,41 \\
\hline & 2017 & 179.126 & 2.706 .395 & 6,62 \\
\hline & 2018 & 150.327 & 2.048 .795 & 7,34 \\
\hline \multirow{3}{*}{$\begin{array}{l}\text { Unilever } \\
\text { Indonesia } \\
\text { Tbk }\end{array}$} & 2016 & $\begin{array}{r}6.390 .67 \\
2 \\
\end{array}$ & 40.053 .732 & 15,96 \\
\hline & 2017 & $\begin{array}{r}7.004 .56 \\
2 \\
\end{array}$ & 41.204 .510 & 17,00 \\
\hline & 2018 & $\begin{array}{r}9.109 .44 \\
5\end{array}$ & 3 & \\
\hline
\end{tabular}

Hasil uji analisis deskriptif yang mengambil data periode pada tahun 2016-2018 melalui 4 data pengamatan perusahaan sub-sektor kosmetik dan keperluan rumah tangga. Deskriptif variabel dalam statistik deskriptif yang digunakan antara lain rata-rata (mean), maksimum, minimum dan standar deviasi. Distribusi statistik deskriptif masing-masing variabel seperti pada tabel berikut: 
Jurnal Manajemen dan Bisnis, Volume 2, No. 1, Juli 2020

Analisis Deskriptif
Descriptive Statistics
\begin{tabular}{|l|r|r|r|}
\hline & Modal & Utang & Profitabilitas \\
& Saham & & \\
\hline N Valid & 12 & 12 & 12 \\
Missing & 0 & 0 & 0 \\
Mean & 55.9125 & 102.8342 & 8.9650 \\
Median & 55.8850 & 79.6700 & 6.3550 \\
Std. Deviation & 18.65269 & 83.13487 & 5.80211 \\
Minimum & 27.36 & 22.54 & 4.70 \\
Maximum & 81.61 & 265.46 & 21.79 \\
\hline
\end{tabular}

1. Variabel Modal Saham (Ratio Modal Asset) memiliki rata-rata sebesar 55,9125, standar deviasi 18,65269, nilai minimum sebesar 27,36, dan nilai maximum sebesar 81,61.

2. Variabel Utang (Debt to Equity Ratio) memiliki rata-rata sebesar 102,8342, standar deviasi 83,13487, nilai minimum sebesar 22,54, dan nilai maximum sebesar 265,46.

3. Variabel Profitabilitas (Net Profit Margin) memiliki rata-rata sebesar 8,9650, standar deviasi 5,80211, nilai minimum sebesar 4,70, dan nilai maximum sebesar 21,79.

Berdasarkan hasil uji multikolonieritas, menunjukkan bahwa tidak adanya multikolonieritas, artinya dalam kasus ini tidak adanya hubungan antara variabel Modal Saham ( $\left.\mathrm{x}_{1}\right)$ dengan Profitabilitas (Y). hasil uji normalitas juga menunjukan sebaran yang merata pada garis lurus, artinya bahwa persyaratan normalitas data telah terpenuhi.

Pengujian hipotesis dalam penelitian ini menggunakan uji persial (Uji t) dan Uji Simultan (Uji f).

Berikut akan dijelaskan masingmasing variabel secara parsial dengan paparan tabel uji t hasil olahan dengan menggunakan statistical product and services solution (SPSS) versi 20.0 dibawah ini:

\section{Hasil Uji Parsial dengan uji t \\ Coefficients $^{\mathrm{a}}$}

\begin{tabular}{|l|r|c|c|c|c|}
\hline Model & \multicolumn{2}{|l|}{$\begin{array}{l}\text { Unstandardize } \\
\text { d Coefficients }\end{array}$} & $\begin{array}{c}\text { Standardi } \\
\text { zed } \\
\text { Coefficie } \\
\text { nts }\end{array}$ & $\mathrm{t}$ & \multirow{2}{*}{ Sig. } \\
\cline { 2 - 4 } & \multicolumn{1}{|c|}{$\begin{array}{c}\text { Std. } \\
\text { Error }\end{array}$} & Beta & & \\
\hline $\begin{array}{l}\text { (Constant } \\
\text { MODAL }\end{array}$ & $\begin{array}{r}28.70 \\
\text { MODA }\end{array}$ & 7.834 & & 3.665 & .005 \\
SAHAM & 4.880 & 1.337 & -3.038 & -3.651 & .005 \\
UTANG & - & .594 & -2.387 & -2.870 & .018 \\
\hline
\end{tabular}

a. Dependent Variable: PROFITABILITAS

\section{a. Pengaruh Modal Saham $\left(\mathbf{X}_{1}\right)$} terhadap Profitabilitas (Y)

Berdasarkan tabel diatas nilai $\mathrm{t}$ hitung $=-3.651$. Nilai $-3.651<$ 2.22814, dengan $\mathrm{H}_{\mathrm{o}}$ ditolak dan $\mathrm{H}_{\mathrm{a}}$ diterima, berarti adanya pengaruh antara variabel Modal Saham $\left(\mathrm{X}_{1}\right)$ terhadap Profitabilitas. Nilai signifikan sebesar 0,005 , maka nilai $0,005<0,05$ hal ini berarti terdapat pengaruh secara signifikan antara variabel Modal Saham $\left(\mathrm{X}_{1}\right)$ terhadap Profitabilitas.

Hasil penelitian ini relavan dengan penelitian terdahulu yang dilakukan oleh Nel Hazrah yang berjudul Pengaruh Perputaran Modal Kerja, Likuiditas, dan Solvabilitas terhadap Profitabilitas (Studi kasus pada PT Astra Internasional Tbk Tahun 2009-2018) yang menyatakan bahwa modal berpengaruh signifikan terhadap profitabilitas. Namun berbeda dengan hasil penelitian yang dilakukan oleh Hariyanti Alimuddin yang berjudul Pengaruh Modal Kerja terhadap Profitabilitas pada PT Semen Tonasa (Persero) di Kabupaten Pangkep, yang menyatakan bahwa modal kerja berpengaruh tidak signifikan terhadap profitabilitas.

\section{b. Pengaruh Utang ( $\left.\mathrm{X}_{2}\right)$ terhadap Profitabilitas (Y)}


Jurnal Manajemen dan Bisnis, Volume 2, No. 1, Juli 2020

Berdasarkan tabel diatas, nilai $\mathrm{t}$ hitung -2.870. Nilai $-2.870<2.22814$, dengan $\mathrm{H}_{\mathrm{o}}$ ditolak dan $\mathrm{H}_{\mathrm{a}}$ diterima, berarti adanya pengaruh antara variabel Utang $\left(\mathrm{X}_{2}\right)$ terhadap Profitabilitas. Nilai signifikan sebesar 0,018 , nilai $0,018<0,05$ berarti terdapat pengaruh secara signifikan antara variabel Utang $\left(\mathrm{X}_{2}\right)$ terhadap Profitabilitas.

Hasil penelitian ini relavan dengan penelitian yang dilakukan yang oleh Aisa Rahmi Syarif yang berjudul Pengaruh Hutang terhadap Profitabilitas perusahaan (Studi pada Perusahaan Food and Beverages yang terdaftar di Bursa Efek Indonesia), yang menyatakan bahwa utang berpengaruh terhadap profitabilitas. Namun penelitian ini berbeda dengan hasil penelitian yang dilakukan oleh Vera Handayani dan Mayasari yang berjudul Analisi Pengaruh Hutang Terhadap Laba Bersih Pada PT. Kereta Api Indonesia (Persero) yang menyatakan bahwa utang tidak berpengaruh signifikan terhadap laba bersih.

\section{c. Pengaruh Modal Saham $\left(X_{1}\right)$ dan Utang $\left(\mathbf{X}_{2}\right)$ terhadap Profitabilitas} (Y)

Uji $F$ digunakan untuk mengetahui ada tidaknya pengaruh secara bersama-sama (simultan) semua variabel independen terhadap variabel dependen.

\section{Hasil Uji Simultan (Uji F)} ANOVA

\begin{tabular}{|l|r|r|r|r|l|}
\hline Model & $\begin{array}{c}\text { Sum of } \\
\text { Squares }\end{array}$ & df & $\begin{array}{c}\text { Mean } \\
\text { Square }\end{array}$ & F & Sig. \\
\hline Regression & 2.878 & 2 & 1.439 & 12.479 & $.003^{\mathrm{b}}$ \\
1 Residual & 1.038 & 9 & .115 & & \\
Total & 3.915 & 11 & & & \\
\hline
\end{tabular}

a. Dependent Variable: PROFITABILITAS

b. Predictors: (Constant), UTANG, MODAL SAHAM
Berdasarkan tabel diatas nilai $\mathrm{F}$ hitung diperoleh sebesar 12.479. Nilai $12.479>4,26$ dengan demikian $\mathrm{H}_{\mathrm{o}}$ ditolak dan $\mathrm{H}_{\mathrm{a}}$ diterima, berarti terdapat pengaruh antara Modal Saham $\left(\mathrm{X}_{1}\right)$ dan Utang $\left(\mathrm{X}_{2}\right)$ secara simultan terhadap Profitabilitas (Y).

Nilai signifikansi diperoleh sebesar 0.003 . Nilai $0,003<0,05$ dengan demikian berarti terdapat pengaruh Modal Saham $\left(\mathrm{X}_{1}\right)$ dan Utang $\left(\mathrm{X}_{2}\right)$ secara simultan terhadap Profitabilitas.

Maka hal ini dapat diartikan bahwa modal saham dan utang sangat berpengaruh terhadap pencapaian profitabilitas suatu perusahaan. Dengan demikian manajemen harus pandai dalam mengelola kekuatan modal yang dimiliki, serta mampu membelanjakan utangnya dengan bijak, sehingga perolehan laba usaha dapat mencapakai titik optimal.

Koefisien determinasi digunakan untuk mengetahui seberapa besar kontribusi atau perubahan yang diberikan variabel bebas terhadap variabel terikat. Berikut adalah tabel yang menjelaskan hasil dari koefisien determinasi.

Hasil Analisis Koefisien Determinasi Model Summary ${ }^{\mathrm{b}}$

\begin{tabular}{|c|c|c|c|c|}
\hline Model & $\mathrm{R}$ & $\begin{array}{c}\mathrm{R} \\
\text { Square }\end{array}$ & $\begin{array}{l}\text { Adjusted } \\
\text { R Square }\end{array}$ & $\begin{array}{c}\text { Std. Error } \\
\text { of the } \\
\text { Estimate }\end{array}$ \\
\hline 1 & $.857^{\mathrm{a}}$ & .735 & .676 & .33956 \\
\hline
\end{tabular}

Tabel diatas, menghasilkan nilai koefisien determinasi atau $\mathrm{R}$ Square = 0,735. Dengan demikian besarnya kontribusi Modal Saham dan Utang terhadap profitabilitas sebesar $73,5 \%$ sedangkan sisanya $26,5 \%$ dipengaruhi oleh faktor-faktor lainnya yang tidak diteliti. 
Jurnal Manajemen dan Bisnis, Volume 2, No. 1, Juli 2020

\section{KESIMPULAN}

Penelitian ini bertujuan untuk melihat pengaruh Modal Saham dan Utang terhadap Profitabilitas. Sampel penelitian ini berjumlah 4 perusahaan dari perusahaan sektor Kosmetik dan Keperluan rumah tangga yang terdaftar di Bursa Efek Indonesia (BEI) dengan periode observasi dari tahun 2016 sampai dengan tahun 2018 yang telah terpilih berdasarkan purposive sampling. Dari hasil pengujian dan analisis hasil penelitian dapat disimpulkan sebagai berikut:

1. Modal Saham berpengaruh signifikan terhadap Profitabilitas. Hal ini dibuktikan dari hasil penelitian nilai uji -t hitung < - $t$ tabel atau $\mathrm{t}$ hitung $>\mathrm{t}$ tabel atau $-3.651<$ 2.22814, dengan demikian terdapat pengaruh Modal Saham terhadap Profitabilitas. Adapun nilai signifikansi sebesar $0,005<0,05$ berarti terdapat pengaruh antara variabel Modal Saham terhadap Profitabilitas. Hal ini dapat dikatakan bahwa modal saham berpengaruh signifikan terhadap profitabilitas.

2. Utang berpengaruh signifikan terhadap Profitabilitas. Hal ini dibuktikan dari hasil penelitian nilai uji t hitung > t tabel atau $-2.870<$ 2.22814, dengan demikian terdapat pengaruh Utang terhadap Profitabilitas. Adapun nilai signifikan sebesar $0,018<0,05$ berarti terdapat pengaruh antara variabel Utang terhadap Profitabilitas. Hal ini dapat dikatakan bahwa utang berpengaruh signifikan terhadap profitabilitas.

3. Modal Saham dan Utang berpengaruh secara bersama-sama terhadap Profitabilitas. Hal ini dibuktikan dari hasil penelitian nilai uji $\mathrm{F}$ hitung > F tabel atau 12.479>
4,26, dengan demikian terdapat pengaruh modal saham dan utang secara simultan terhadap profitabilitas. Adapun nilai signifikansi $<0,05$ atau $0,003<0,05$ dengan demikian terdapat pengaruh modal saham dan utang secara simultan terhadap profitabilitas.

Dengan demikian manajemen perusahaan harus dengan cermat memperhatikan komposisi modal dan utang yang ada pada perusahaannya, dengan segala ketentuan dan harapan yang melekat pada investor maupun pemberi kreditur. Dengan pengelolaan modal dan utang yang cermat, maka profitabilitas perusahaan dapat dimaksimalkan. Sehingga keberhasilan kinerja manajemen dapat diapresiasi oleh pemegang saham maupun kreditur.

\section{REFERENSI}

Fahmi, Irham. 2014. Manajemen Keuangan Perusahaan dan Pasar Modal. Jakarta: Mitra Wacana Media.

Hariyanti, Alimudin. 2019. Pengaruh Modal Kerja terhadap Profitabilitas pada PT Semen Tonasa (Persero) di Kabupaten Pangkep. Skripsi. Universitas Negeri Makasar.

Handayani, Vera dan Mayasari. 2018. Analisis Pengaruh Hutang terhadap Laba Bersih pada PT. Kereta Api Indonesia (PERSERO). Jurnal Riset Akuntansi \& Bisnis Vol 18 No.1. Sumatera Utara. Universitas Muhammadiyah.

Hazrah, Nel, Saprudin, dan Tiur. 2019. Pengaruh Perputaran Modal Kerja, Likuiditas dan Solvabilitas Terhadap Profitabilitas (Studi kasus pada PT Astra Internasional Tbk Tahun 20092018). Journal of Information System, Applied, Management, Accounting and Research Vol 3 No.4. Jakarta. STMIK Jayakarta. 
Jurnal Manajemen dan Bisnis, Volume 2, No. 1, Juli 2020

Hery. 2016. Akuntansi Aktiva, Utang, dan Modal. Yogyakarta: Gava Media.

Hery. 2018. Teori Akuntansi. Jakarta: Prenadamedia Group.

Hestanto. 2019. Teori Keagenan Menurut Cendekiawan.

Kasmir. 2016. Analisis Laporan Keuangan. Jakarta: PT Raja Grafindo Persada.

M, Suparmako dan Icuk Rangga Bawana. 2007. Ekonomi SMA Kelas XI. Jakarta: Yudhistira.

Munawir. 2014. Analisis Laporan Keuangan Edisi 4 Cetakan 16. Yogyakarta: Liberty.

Rudianto. 2018. Akuntansi Intermediate IFRS. Jakarta: Erlangga.

Syarif, Aisa Rahmi.2016. Pengaruh Hutang terhadap Profitabilitas perusahaan (Studi pada Perusahaan Food and Beverages yang terdaftar di Bursa Efek Indonesia). Skripsi. Universitas Muhamadiyah Malang

Hartanto, William. 2019. Analis: emiten kosmetik harus lebih bersolek lewat iklan. Investasi.kontan.co.id.

Silaen, Sofar dan Widiyono. 2013. Metodologi Penelitian Sosial untuk Penulisan Skripsi dan Tesis. Jakarta: In Media.

Sudaryo, Yoyo, dkk. 2017. Keuangan di Era Otonomi Daerah. Yogyakarta: Penerbit Andi (Anggota IKAPI)

Sugiyono. 2016. Metode Penelitian Kualitatif, Kuantitatif dan $R \& D$. Bandung: Alfabeta.

Sutedi, Adrian. 2015. Buku Pintar Perseroan Terbatas. Jakarta: Raih Asa Sukses.

Undang-undang No 40 Tahun 2007 tentang Perseroan Terbatas.

Wismonoto. 2017. 3 Penyebab besar Bangkrutnya Pabrik Jamu Legendaris Nyonya Meneer. Tribunwow.com.
Yulianto, Ali Akbar dan Krista. 2007. Pengantar Bisnis Edisi 4 Buku 2. Jakarta: Salemba Empat.

Website:

www.idx.co.id 